\title{
MCL1 wt Allele
}

National Cancer Institute

\section{Source}

National Cancer Institute. MCL1 wt Allele. NCI Thesaurus. Code C49423.

Human MCL1 wild-type allele is located in the vicinity of $1 \mathrm{q} 21$ and is less than $1 \mathrm{~kb}$ in length. This allele, which encodes induced myeloid leukemia cell differentiation protein $\mathrm{Mcl}-1$, plays a regulatory role in apoptosis. 